\title{
Las desconocidas de la Revolución
}

\section{Carla Hernández}

Hablamos mucho de la Revolución mexicana y de hecho es una de las fechas más importantes. Recuerdo que cuando vivía en México siempre tuve la duda de por qué el 20 de noviembre era más importante que el 16 de septiembre. Siempre me pareció algo extraño que la Revolución fuera más importante que la Independencia, pero nunca tuve mucho afán de entender. Desde muy pequeña empecé a leer libros de historia y en la escuela era una de las materias más interesantes, pero ahora entiendo que en la escuela sólo enseñan una parte de la historia. En la escuela yo sólo escuché cosas increíbles de los héroes revolucionarios como Pancho Villa, Emiliano Zapata, Venustiano Carranza entre otros. Fue sino hasta que yo empecé a buscar mi propio conocimiento que me di cuenta que, aunque estos sí ayudaron mucho al país, también eran hombres ambiciosos que muchas veces no les importaba herir a otras personas para conseguir lo que querían aun cuando esto no fuera bueno.

También me di cuenta que estos hombres no lucharon solos; esto es algo que ya sabía pero como en la escuela sólo se enfocaban en estas personas no consideré a los demás. Ahora me doy cuenta que sin todos los hombres y mujeres que dejaron sus vidas por la Revolución, esta hubiera sido un rotundo fracaso. Lo que más me sorprendió al empezar mi investigación fue el poco o a veces nulo reconocimiento a las mujeres durante la Revolución. Claro que cada año las mujeres nos vestíamos de "adelitas" para los desfiles, pero nunca supe por qué les decían así. Por esto, creo que se debe hacer un mayor enfoque en las mujeres, que también arriesgaron su vidas. 


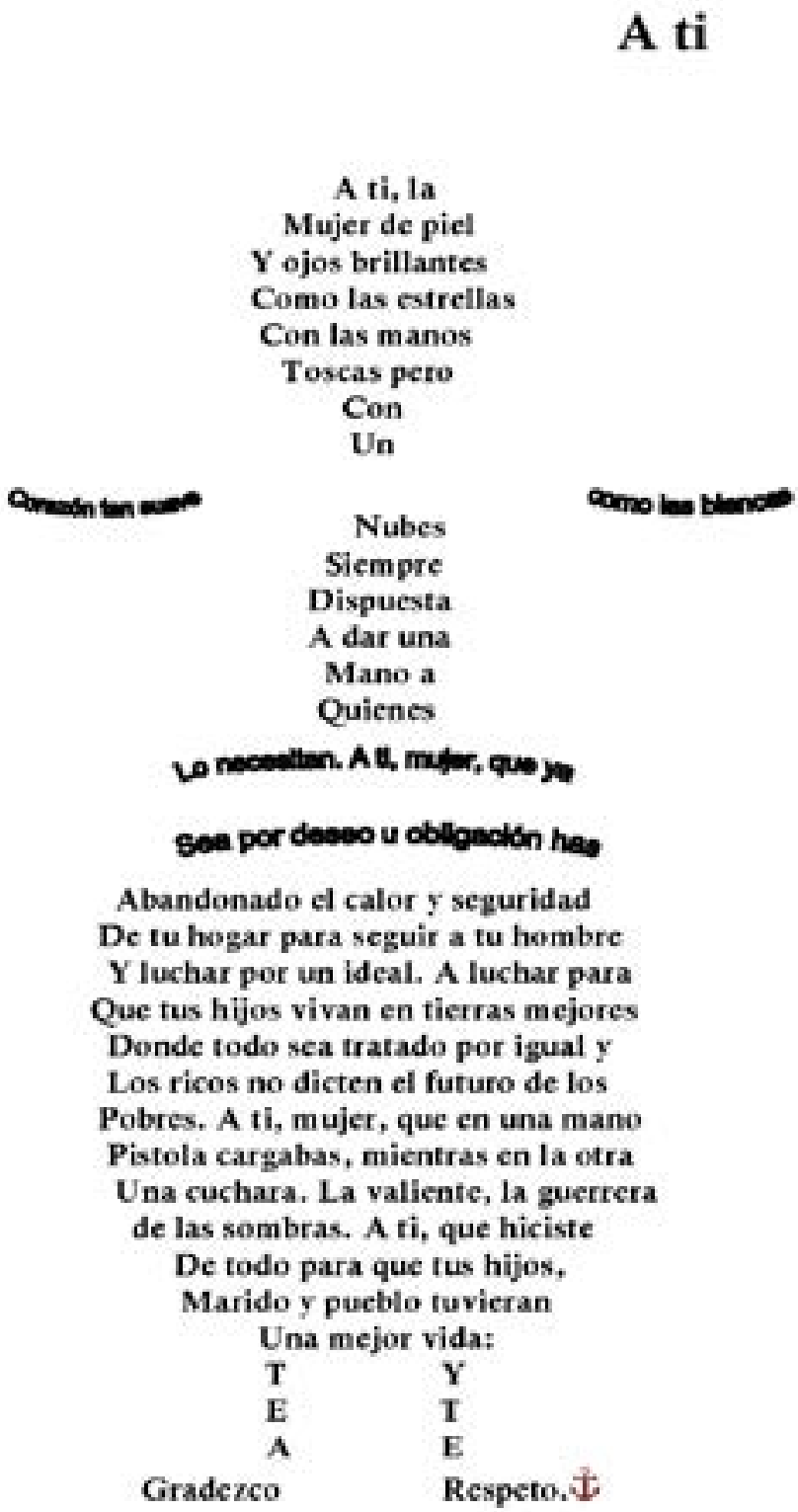

